\title{
Endangering of Businesses by the German Inheritance Tax? - An Empirical Analysis
}

Henriette Houben, Institute of Business Taxation, Leibniz University of Hannover, Germany, E-mail: houben@steuern.uni-hannover.de RalfMaiterth, Institute of Business Taxation, Humboldt-University of Berlin, Germany, E-mail: ralf.maiterth@wiwi.hu-berlin.de

\begin{abstract}
This contribution addresses the substantial tax privilege for businesses introduced by the German Inheritance Tax Act 2009. Advocates of the vast or even entire tax exemption for businesses stress the potential damage of the inheritance tax on businesses, as those often lack liquidity to meet tax liability. This submission tackles this issue empirically based on data of the German Inheritance Tax Statistics and the SOEP. The results indicate that former German inheritance tax law has not endangered transferred businesses. Hence, there is no need for the tremendous tax privilege for businesses in current German inheritance tax law. An alternative flat inheritance tax without tax privileges, which meets revenue neutrality per tax class according to current tax law, provokes in some cases relative high tax loads which might trouble businesses.
\end{abstract}

Keywords: inheritance tax, liquidity effect, family business, tax privilege for businesses

Manuscript received May 2, 2010, accepted by Rainer Niemann (Accounting) February 22, 2011.

\section{Introduction}

The German Inheritance Tax Reform Act 2009 has been provoked by the jurisdiction of the Federal Constitutional Court. The court found fault with the erratic results of the valuation procedures for businesses and real estate in previous German inheritance taxation and the resulting unequal taxation (BVerfG v. 7.11.2006, 1 BvL 10/o2: recital 136). However, a privileged taxation of distinct asset categories is according to the Federal Constitutional Court acceptable if this is in general public interest. But a preferential treatment must not take place in tax valuation procedures. Therefore, all asset categories are supposed to be assessed by market values through new designed valuation procedures.

Nucleus of the new German inheritance tax is a vast or even an entire tax exemption for transferred businesses which is justified by job protection. A privileged taxation of businesses is not a particular German issue. For instance, the UK inheritance tax provides with its "business property relief" a tax privilege for businesses similar to the German regulation. Tax privileges for businesses in general respectively for family-owned businesses can also be found in various countries, such as France, Ireland, Spain and Sweden. But there are also countries without tax privileges for firms, e.g., Denmark, Luxemburg, Japan and the Netherlands. In the USA a provision allowing qualified family-owned businesses to shelter up to $\$ 1.3$ million from estate taxes was eliminated in 2004. But the US estate tax still provides a tax privilege for family-owned businesses as farmers and small business owners may reduce the value of their real estate using a special formula (Burman, Gale, and Rohaly 2005).

The German government stresses the importance of small-scale companies for economic growth and employment in Germany. The rationale for a differential taxation in favor of businesses is possible liquidity problems caused by the inheritance tax. Complaints about the negative effects on passing businesses onto children or other relatives due to restraints in entrepreneurial liquidity are not a specific German feature. This issue also provokes controversial discussions in other countries, e.g., the USA, although, similar to Germany, the inheritance tax contributes only minimally to overall tax revenue. Not surprisingly, especially owners of family 
businesses indicate that the inheritance tax would make survival of their business more difficult if not impossible (Holtz-Eakin, Phillips, and Rosen 2001: 52; Travis Research Associates 1995: 3).

The objective of this contribution is to figure out if the tax privilege for businesses in current German inheritance tax law can be justified. As neither a negative effect nor the irrelevance of the inheritance tax on the passing of businesses to heirs or donees can be proven theoretically, we approach this topic empirically. For that purpose we quantify the inheritance tax burden of transferred businesses empirically by exploiting data of the latest inheritance tax statistics of the Federal Statistical Office Germany. We calculate both the tax burden in case of former German inheritance tax law and the tax burden in case of an alternative inheritance tax without any tax privileges and lower tax rates. Simultaneously, we examine the environment in which transfer of businesses takes place. In this context we assess to what extent transferees of (family) businesses are able to cover their inheritance tax liability by any but business assets. At least, this enables us to make a rough estimate of whether the inheritance tax really causes the negative effects on family businesses stated and, subsequently, if a tax privilege for businesses can be justified.

The remainder of this paper is structured as follows: section 2 highlights the former and current taxation of transferred businesses in German inheritance tax law. In section 3 pros and cons of a tax privilege for businesses are discussed and previous empirical findings are presented. In section 4 we present our microsimulation model, in section 5 we discuss our empirical findings, and section 6 results in the conclusion.

\section{Business Transfers in former and current German inheritance tax law}

\subsection{A brief German Inheritance Tax Act- overview}

The German Inheritance Tax Act (Erbschaft- und Schenkungsteuergesetz, ErbStG) applies to transfers of property and with it transfers of businesses regardless of whether a transfer results from heritage or donation. Subject to tax is the enrichment of the recipient (and not the estate of the bequeather as in estate tax) valued according to the German
Valuation Tax Act (Bewertungsgesetz, BewG). Previous donations within the last ten years are added (Sec. 14 ErbStG) and tax exemptions (e.g., for businesses according to Sec. 13a ErbStG) are stripped just as personal allowances. The resulting so-called "taxable enrichment" is subject to a progressive tax scale. Both personal allowances and tax rates differ according to the degree of relationship. Tax class I comprises spouses, children, grandchildren and, in case of heritage, parents and grandparents. Tax class II contains other close relatives and tax class III applies in particular to unrelated individuals (Sec. $15 \mathrm{ErbStG}$ ). The tax scale is directly progressive and it is a graduated rate. This means there is one particular tax rate depending on the taxable enrichment. In case of transferred businesses Sec. 19a ErbStG provides the application of the (beneficial) tax rate according to tax class I.

Table 1 depicts personal allowances according to former and current inheritance tax law.

\section{Table 1: Personal allowances according to inheritance tax status 2008 and 2009 (Sec. 16 ErbStG)}

\begin{tabular}{clcc}
$\begin{array}{c}\text { Tax } \\
\text { class }\end{array}$ & $\begin{array}{l}\text { Degree of } \\
\text { relationship }\end{array}$ & $\begin{array}{c}\text { Former tax } \\
\text { law in euros }\end{array}$ & $\begin{array}{c}\text { Current tax } \\
\text { law in euros }\end{array}$ \\
\hline I & spouses & 307,000 & 500,000 \\
\hline I & children & 205,000 & 400,000 \\
\hline I & grandchildren & 51,200 & 200,000 \\
\hline I & others & 51,200 & 100,000 \\
\hline II & no differentiation & 10,300 & 20,000 \\
\hline III & no differentiation & 5,200 & 20,000 \\
\hline & & &
\end{tabular}

The notable increase of tax rates in tax class II and III results from the intended revenue neutrality of the tax reform. However, it has no impact on businesses since they are always subject to tax class I as long as the transfer is not tax-free at all.

\subsection{Taxation of businesses according to former German inheritance tax law}

The former German inheritance tax law granted businesses (sole proprietorships, partnerships and substantial shareholding ( $>25 \%$ ) in corporations) three privileges: First, the average tax value of businesses fell below market value. Tax values of sole proprietorships and partnerships amounted on average to about $50 \%$ of market values whereas shares in non-listed corporations were ordinary rated with $70 \%$ of their market value (Sureth, Mül- 
ler, Houben, and Maiterth 2008: 193-195). Further, former inheritance tax law provided two explicit tax privileges for businesses (Sec. 13a and 19a ErbStG 2008). Sec. 13a ErbStG 2008 provided a tax allowance of 225,000 euros for every business as well as assessing the remainder only with $65 \%$. If a business was transferred to an individual who belongs to tax class II or III, $88 \%$ of the business was taxed according to the (lower) rate of tax class I (Sec. 19a ErbStG 2008). The last two privileges required the business not being sold within five years after its transfer. Table 2 illustrates nominal tax rates according to the inheritance tax status 2008 and 2009.

\section{Table 2: Inheritance tax scale according to inheritance tax status 2008 and 2009 (Sec. 19 ErbStG)}

\begin{tabular}{c|ccccccc}
$\begin{array}{l}\text { Taxable en- } \\
\text { richment in } \\
\text { thousand } \\
\text { euros up to }\end{array}$ & $\begin{array}{l}\text { Tax rates in \% } \\
\text { class I }\end{array}$ & $\begin{array}{l}\text { Tax } \\
\text { class II }\end{array}$ & \multicolumn{3}{l}{ Tax } \\
class III & \\
\hline 2008 & 2009 & $\begin{array}{l}2008 / \\
2009\end{array}$ & 2008 & 2009 & 2008 & 2009 \\
\hline 52 & 75 & 7 & 12 & 30 & 17 & 30 \\
\hline 256 & 300 & 11 & 17 & 30 & 23 & 30 \\
\hline 512 & 600 & 15 & 22 & 30 & 29 & 30 \\
\hline 5,113 & 6,000 & 19 & 27 & 30 & 35 & 30 \\
\hline 12,783 & 13,000 & 23 & 32 & 50 & 41 & 50 \\
\hline 25,565 & 26,000 & 17 & 37 & 50 & 47 & 50 \\
\hline Beyond & & 30 & 40 & 50 & 50 & 50 \\
\hline
\end{tabular}

\subsection{Vast or entire tax exemption for businesses in current German inheritance tax law}

The vast or entire tax exemption of businesses (Sec. 13a and 13b ErbStG 2010) is the crucial and most controversial issue of German Inheritance Tax Reform Act 2009.

The vast tax exemption of businesses forms the rule and releases businesses up to $85 \%$ from taxation (Sec. 13b Para. 4 ErbStG), and it is officially guaranteed. In addition, Sec. 13a Para. 2 ErbStG provides a tax allowance of 150,000 euros for the remaining $15 \%$. This tax allowance will be reduced if the remaining $15 \%$ exceeds 150 ,ooo euros. The reduction amounts to $50 \%$ of the exceeding value.

The 85\%-tax exemption will be granted only if the following requirements are fulfilled:
- Non-productive assets in terms of Sec. 13b Para. 2 ErbStG must not account for more than 50\% of all assets. Otherwise, $100 \%$ of business assets are subject to inheritance tax.

- Within five years after the transfer of a business aggregate wages must not fall below $400 \%$ of average wages paid per year before transferring the business (so-called job clause of Sec. 13a Para. 1 ErbStG). If aggregate wages fall below the threshold of $400 \%$ the $85 \%$-tax exemption is reduced according to the shortfall of aggregate wages.

- A sale of the business within five years after its transfer leads to a reduction of the 85\%-tax exemption on a pro-rata basis (so-called salesclause of Sec. 13a Para. 5 ErbStG). If sales revenues are reinvested the tax privilege remains unaffected. Excessive withdrawals cause a reduction of the $85 \%$ tax exemption in either case.

The non-tax-exempt fraction of business assets benefits from the tax privilege of Sec. 19a ErbStG and is taxed according to tax class I irrespective of the degree of relationship.

Alternatively to the $85 \%$-tax exemption an entire tax-free transfer of a business can be claimed (Sec. 13a Para. 8 ErbStG) if the following restrictive requirements are fulfilled:

- Non-productive assets in terms of Sec. 13b Para. 2 ErbStG must not add up to more than $10 \%$ of all assets.

- The aggregate wage rule holds for seven years. Within this period $700 \%$ of the average wages per year before transferring the business must be paid.

- The retention period is ten instead of seven years.

According to the jurisprudence of the Federal Constitutional Court the new valuation procedures for businesses (Sec. 199-203 BewG) are supposed to result in market values. Businesses have to be assessed even in case of claiming for an entire tax-free transfer of businesses according to Sec. 13a Para. 8 ErbStG.

\section{Pros and cons for an inheritance tax privilege for businesses}

The most popular argument in favor of an inheritance tax privilege for businesses is the potential negative effect on family businesses and as a result on jobs due to the negative liquidity effect (see, e.g., 
Astrachan and Tutterow 1996; Brunetti 2006; Harris 1949; Holtz-Eakin, Phillips, and Rosen 2001). This is also stated by the German Government to justify the introduction of the comprehensive tax privilege for businesses. Inheritance tax can jeopardize businesses due to liquidity problems if the transferees of a business lack liquid assets to meet inheritance tax liability and if, in addition, imperfect capital markets inhibit refunding. Furthermore, advocates of an inheritance tax privilege for businesses stress the specialized leading skills of relatives resulting from their particular identification and family-specific know-how (Bennedsen, Nielsen, Pérez-González, and Wolfenzon 2007). Additional$\mathrm{ly}$, it is stated that principal-agent problems are less virulent. This leads to the conclusion that businesses should remain within the family for welfare reasons and therefore a tax privilege is justified.

However, there are several arguments that challenge this perception. To keep the management inside a family reduces the pool of capable managers considerably without a need (Maiterth, Niemann, Blaufus, Kiesewetter, Knirsch, König, Hundsdoerfer, Müller, Sureth, and Treisch 2006; Sachverständigenrat 2008). Furthermore, empirical findings on the performance of businesses run by families or heirs in Denmark, France, Germany, the USA and the UK militate against a tax privilege. Bloom and Van Reenen (2006) found that mismanagement will occur in particular if a business is transferred to the eldest son (primogeniture), whereas the management abilities will not be affected if the entire family appoints the management of a transferred business. In contrast, Morck, Shleifer, and Vishny (1989), Bennedsen, Nielsen, PérezGonzález and Wolfenzon (2007), Pérez-González (2006) and Villalonga and Amit (2006) discovered in general a significantly poorer performance of companies run by heirs compared to firms with non-family executives. Grossmann and Strulik (2010) disapproved an inheritance tax privilege for businesses in a general equilibrium model. In their findings lower management skills dominate transaction cost savings. However, if the government decides to introduce a tax privilege, there should be no link to the business being continued by the heirs. A preferential taxation of firms can also not be justified by risk-taking aspects (Jansen 2006: 200).

A further argument against an inheritance tax privilege for businesses is provided by the resulting considerable compliance costs of such a regulation.
Looking at Sec. 13a and 13b ErbStG reveals that there are considerable enforcement costs in form of declaration costs for taxpayers as well as control costs for tax authorities. A tax privilege for particular asset categories requires a clear distinction of privileged and unprivileged assets. Since a definite classification of asset categories cannot be delivered, taxpayers face enormous incentives and as a result high tax planning costs to re-qualify unprivileged into privileged assets. This in turn causes (costly) defense action by the tax authorities. These significant compliance costs would not emerge from an inheritance tax with a broad tax base and thus without a differential treatment of asset categories.

Another remarkable aspect are measures taken by entrepreneurs to minimize the impact of inheritance tax on the transfer of their business. As empirical findings indicate, entrepreneurs take - generating deadweight costs - actions to minimize the impact of the inheritance tax on the transfer of their business (Astrachan and Tutterow 1996; Holtz-Eakin 1999; Holtz-Eakin, Phillips, and Rosen 2001). This might be the reason for the lack of empirical evidence that the former German inheritance tax caused liquidation or sales of firms. This view has been confirmed by the German Minister of Finance Peer Steinbrück in a debate on the Inheritance Tax Reform, who was in charge when the German Inheritance Tax Reform Act 2009 took place.

Another relevant aspect against a tax privilege for businesses in form of a tax exemption is the lack of accuracy of this measure. Even if public welfare or other reasons required businesses to stay within a family, a general tax exemption would not be the appropriate measure to assure this. Liquidity problems which, as mentioned above, could result from capital markets imperfections would be mitigated properly by a tax deferral regulation (Maiterth, Niemann, Blaufus, Kiesewetter, Knirsch, König, Hundsdoerfer, Müller, Sureth, and Treisch 2006; Bach, Broekelschen, and Maiterth 2006: 1967; Hey 2007: 573; Sachverständigenrat 2008: 366). However, a general tax exemption can by no means be justified. Furthermore, with respect to tax-induced liquidity problems it has to be kept in mind that an inheritance tax law with no exemptions enables remarkably lower tax rates, as will be shown later on. This in turn could mitigate liquidity problems to a large extent, if not eliminate them.

Last but not least, the perception of a particular tax as fair or unfair plays a crucial role in its acceptance. 
If a tax is regarded as fair, people will be less reluctant to pay than if they regard the tax as unfair (Schneider and Enste 2000: 93 f.). Since the current German inheritance tax burden of an individual crucially depends on the asset category of the bequest it might presumably be regarded as unfair. But it remains unclear to what extent the jobprotection argument countervails this perception.

Summing up the arguments, neither a negative effect of the inheritance tax on family businesses nor its innocuousness can be proven theoretically. In the end, it is an empirical question if or, respectively, to what extent an inheritance tax causes liquidity problems for businesses. Some empirical results in this context are provided subsequently.

Harriss (1949) tackled problems such as timing or matching problems, which may occur, when assets of a business have to be sold to meet the US estate tax liability. The findings, based on data from Statistics of Income for estates filed in 1942-1944, show for the vast majority of taxable estates no difficulties in transforming assets into cash to pay the estate tax. But for a small number of extremely valuable estates (these cover $47 \%$ of total tax revenue) liquidity fails to balance the estate tax liability.

Astrachan and Tutterow (1996) dealt with the question of whether and how the US estate tax affects business behavior by a telephone poll of 1,003 businesses where nearly $80 \%$ were family businesses. The results of the survey suggest that estate taxes cause business owners to alter the management of their enterprises in ways that depress economic activity. The entrepreneurs stated they invest less and create fewer jobs than they would if they did not face the prospect of estate taxes. With regard to a transfer of their business, $66 \%$ of the respondents claimed threats to business survival and $8 \%$ presume the death of their business.

Holtz-Eakin (1999) analyzed behavioral responses to the estate tax. Based on data collected in a mail survey sent to businesses in upstate NY his econometric results show a considerable negative relationship between the number of jobs created in the past five years and future estate tax liability. HoltzEakin concluded "that the estate tax is shiftedforward in time to the business operation and onto the production factors capital and labor".

Holtz-Eakin, Phillips and Rosen (2001) examined whether and how people use life insurance to hedge US estate tax and avoid liquidity problems. Their findings rely on a pooled database of two nationally representative samples of older persons for a specific year (HRS and AHEAD). Their findings suggest that owners of businesses buy more insurance than other individuals do, but, even together with other liquid assets, they cannot balance estate tax liability. Brunetti (2006) estimated if, and to what extent, the US estate tax forces sales of family business and farm. His econometric analysis is based on the probate records of the San Francisco County Superior Court from 1980 to 1982, which include 312 estates that contain businesses or farms. The paper shows a positive and significant relationship between the estate tax and business sales.

Unfortunately, the results of these empirical papers do not provide a satisfactory answer to the question of whether the German inheritance tax endangers businesses. Harriss (1949), Holtz-Eakin (1999) and Holtz-Eakin, Phillips, and Rosen (2001) did not draw any conclusions as to whether estate taxes endanger family businesses. Although the findings of Astrachan and Tutterow (1996) and Brunetti (2006) suggested a distinct negative impact of the US estate tax on the transfer of businesses the results cannot be applied straight to Germany. The main reason is the remarkable higher tax load of businesses by the US estate tax compared to the German inheritance tax as a result of remarkable higher US tax rates. In addition, the conclusions of Astrachan and Tutterow (1996) were based on a survey of entrepreneurs, which presumably might provide distorted results as almost every survey offers complaints about taxation by the respondents. Besides, the findings of Brunetti (2006) are not entirely convincing as he discovered that the liquidity effect, regularly made responsible for the negative effect of estate respectively inheritance taxes, is statistically not significant. That means the results do not support a liquidity link to business sales. Brunetti (2006: 1989), stated in this context: "it is difficult to understand why the estate tax effect is large while the liquidity effect is not". Furthermore, it has to be taken into account that the sample is very small; it contains only 312 estates that include businesses in a time period of 4 years from which only a small fraction was sold (e.g., in 1982 there were only $14.7 \%$ of $116=17$ businesses sold). To assess the impact of the German inheritance tax on liquidity of transferred firms we quantify the inheritance tax burden of each transferred businesses empirically within the framework of the microsimulation model ErbSiHM 1.1 based on the data 
of the latest inheritance tax statistics of the Federal Statistical Office Germany. Unfortunately, the data merely contain information about the inheritance tax status of the transferee of a business but lack information of what happens to the business after being transferred. Hence, we cannot prove in an econometric model if or, respectively, to what extent the German inheritance tax forces business sales. But we can tackle the problem by gaining deeper insights into (possible) liquidity problems caused by the inheritance tax, which allows some sound predictions of whether tax privileges for businesses can be justified.

\section{Microsimulation model ErbSiHM 1.1}

\subsection{Model structure}

Our microsimulation model ErbSiHM 1.1 (for a detailed description of ErbSiHM 0.1 which is a former version of ErbSiHM 1.1 see Houben and Maiterth 2010) employs two databases. The main database is the (latest) inheritance tax statistics 2007 of the Federal Statistical Office Germany (subsequent ITS 2007). As ITS 2007 does not contain transfers of property in its entirety, we have completed ITS 2007 by means of the data of the socio-economic panel (SOEP) of the German Institute for Economic Research. ErbSiHM 1.1 is a static microsimulation model and we have renounced static ageing. This model structure results from two aspects: First, we analyze whether the former German inheritance tax endangered businesses. For this purpose neither static ageing nor the use of a dynamic model is necessary or even fruitful. Second, we analyze the impact of an (future) alternative inheritance tax which makes static ageing as well as a dynamic model structure desirable. Unfortunately, we lack information on behavioral response to (changes in) inheritance tax, which leads to the static model structure. As far as we know there are neither reliable estimation results of tax elasticity nor data existing that would allow such estimations. Furthermore, behavioral response to inheritance tax is presumably relatively moderate as it requires both transfer of property and the removal of the decedent as well as the recipient (Sachverständigenrat 2008: 371). We refrained from static ageing as an extrapolation according to numbers of property transfers does not alter the revenue-neutral tax rates in our alternative inheritance tax system, and alternative extrapolation scenarios fail due to lack of information.

\subsection{Microsimulation model based on inheritance tax statistics 2007}

The latest data of the inheritance tax statistics of the German Federal Statistical Office originate from 2007 and this is our main data source. ITS 2007 contains micro data of every single transfer of property if an inheritance tax assessment in 2007 took place. If it is foreseeable that if no tax assessment will happen (tax value of property < personal allowance) then property transfers are not included in ITS 2007. ITS 2007 provides detailed information which enabled us to establish our microsimulation model. For example, ITS 2007 offers information whether a property is transferred via heritage or donation. In addition, it reveals the composition of the property, the tax class, the amount of taxable enrichment and tax liability. This enables us to calculate for each transferee his taxable enrichment and his tax liability according to the former inheritance tax law and an alternative inheritance tax without privileges. Furthermore, any detailed information about asset categories allow for identification of transferred businesses and for analyzing their tax situation.

ITS 2007 is the most comprehensive database for analyzing German inheritance tax empirically. It comprises 214,232 transfers of property whereof 154,402 transfers result from heritage and 59,830 from donations. Within the 214,232 transfers of property 27,942 (13.5\%) regard transfers of a business. Most of the aggregate tax base (68\%) is taxed according to tax class I, though only $31 \%$ of all transfers take place within this tax class. ITS 2007 displays tax revenue of 4.2 billion euros which serves as a reference parameter for the simulation of an alternative revenue-neutral inheritance tax with a broad tax base and low tax rates. Tax revenues result from an aggregate tax base (incl. former donations) of 28 billion euros. The underlying transfer of net property in tax values accounts for 35 billion euros.

Since ITS 2007 provides only tax values, except for "composite donations" as a subgroup of donations, market values have to be imputed. The imputation of market values is inevitable for the simulation of an alternative inheritance tax without tax privileges as well as for the SOEP-based component of ErbSiHM 1.1. For the imputation we employed mar- 
ket value multipliers which were gained empirically from other contributions. Market value multipliers for businesses were identified by Sureth and J. Müller based on DataStream (see in detail Maiterth and Sureth 2007: 39-42 and 51-57; Sureth, Müller, Houben, and Maiterth 2008: 192-195). The empirically obtained ratio of market value to tax value (market value multiplier) for sole proprietorships and partnerships is 1.8572 and for shares of nonlisted corporations 1.4493. The empirical market value multiplier for real estate is based on purchase price data for Berlin and the underlying ratio of tax value to market value was established by Broekelschen and Maiterth (2008: 530). The multiplier of 1.4286 is roughly confirmed in subsequent analyzes based on purchase price data for Lower Saxony. For the imputation of market values of agriculture and forestry businesses we adopted a multiplier of 4 developed by the German Ministry of Finance. The in terms of German Inheritance Tax Act so-called "residual property" is stated at market values. As this asset category consists predominantly of assets such as bank account, cash and stock market valuation do not cause problems in the majority of cases. Other assets like jewelry or objects of art, which are more difficult to assess, are of minor importance. By imputing market values into the ITS 2007 the transfer of net property in market values accounts for 48 billion euros. This is an increase of around $37 \%$ compared to figures in tax value.

\subsection{SOEP-based supplementary model}

The interaction of personal tax allowances and undervaluation of businesses and real estate according to the former German Valuation Tax Act results in a considerable under-recording of transfers of property in ITS 2007. To cover this data gap we have employed the SOEP data and developed a SOEP-based supplementary model. In a first step, we imputed tax classes into SOEP on the basis of the figures of ITS 2007. Then we classified both ITS 2007 data and SOEP data according to transferred net property in market values broken down by tax classes and by heritage versus donation. Subsequently, we compared classified data of ITS 2007 and SOEP with respect to population density. The results show - as we expected - an under-recording of transfers of low-value property in ITS 2007, whereas transfers of high-value property are under-recorded in SOEP. In cases of heritage transfers of property up to 550,000 euros are under-recorded in ITS 2007. In cases of donation this holds for transfers of property up to 350,000 euros. We solved the problem of under-recording in ITS 2007 by adding transfers of property which are not recorded in ITS 2007 to this database (SOEP-based supplementary model). We created new datasets within the low-value property population of ITS 2007 by multiplying each dataset of ITS 2007 in a particular property class until the same amount of transfers occurred as in the corresponding SOEP population (SOEP-based supplementary population). Thus, the ITS 2007 population was boosted by approximately 674,000 transfers of property with an aggregate net property value of 23 billion euros.

\subsection{Reliability of ErbSiHM 1.1}

We proved the quality of ErbSiHM 1.1, and with it the reliability of our results, by checking aggregate values calculated by ErbSiHM 1.1 against displayed values in (original) ITS 2007. Table 3 depicts aggregate tax base and aggregate tax liability displayed and calculated for the entire ITS 2007 population. The comparison of calculated with displayed values proves the reliability of the employed attributes of ITS 2007. In addition, it shows how precise the tax assessment procedure is reproduced by ErbSiHM 1.1. A further quality check was made for the imputation of market values into ITS 2007. For this purpose we compared imputed market values with displayed market values for the subpopulation of composite donations, for which ITS 2007 comprises market values.

Table 3: Displayed and calculated aggregate values on bases of the (original) ITS 2007 population

\begin{tabular}{lllc} 
& $\begin{array}{l}\text { Aggregate } \\
\text { tax base } \\
\text { in million } \\
\text { euros }\end{array}$ & $\begin{array}{l}\text { Aggre- } \\
\text { gate tax } \\
\text { liability } \\
\text { in million } \\
\text { euros }\end{array}$ & $\begin{array}{l}\text { Market val- } \\
\text { ues in million } \\
\text { euros (sub- } \\
\text { population } \\
\text { composite } \\
\text { donations) }\end{array}$ \\
\hline $\begin{array}{l}\text { Displayed in } \\
\text { ITS 2007 }\end{array}$ & 28,182 & 4,221 & 2,993 \\
\hline $\begin{array}{l}\text { Calculated } \\
\text { by ErbSiHM } \\
1.1\end{array}$ & 28,052 & 4,212 & 2,965 \\
\hline Difference & $-0.461 \%$ & $-0.213 \%$ & $-0.936 \%$ \\
\hline
\end{tabular}

Table 3 shows only marginal differences between calculated and displayed values. This is in particular remarkable with respect to our relatively rough 
market value imputation factors. Our market value imputation is conducted in the form of mean imputation and therefore certainly limited on an individual basis. But, overall, the market value imputation seems to work pretty well as Table 3 shows. These results provide proof of the reliability of the employed microsimulation model ErbSiHM 1.1 as well as of the quality of the applied imputation procedure. Hence, the subsequently represented results can be rated as reliable.

\section{Empirical Results}

\subsection{Tax rates in case of an inheritance tax without tax base privileges}

In the following chapter, our focus is not only on analyzing potential liquidity problems caused by the former German inheritance tax. We also investigate possible damage of a revenue-neutral inheritance tax law without privileges, neither with respect to tax base nor to tax rates. For this purpose we have considered an alternative (uniform) inheritance tax law, based on current law, with the exception of tax privileges for businesses and real estate. In order to make the alternative inheritance tax law comparable to the former German inheritance tax we consider the tax rates of $30 \%$ respective $50 \%$ in tax class II applied in 2009 as the Inheritance Tax reform Act 2009 was supposed to be revenue neutral. This does not hold for the in 2010 established lower tax rates in tax class II.

As there are several alternatives to gain tax neutrality in such a tax system, we have calculated tax rates that assure revenue neutrality within each tax class. Table 4 shows to what extent tax rates in each tax class could be reduced if the tax privileges in the current inheritance tax law were abolished.

Table 4: Tax rate cuts and top tax rates in case of revenue neutrality per tax class

\begin{tabular}{llll}
\multicolumn{3}{c}{ Tax classes } & \\
& I & II & III \\
\hline $\begin{array}{l}\text { Reduction of } \\
\text { tax rates }\end{array}$ & $59 \%$ & $23 \%$ & $19 \%$ \\
\hline $\begin{array}{l}\text { Range of tax } \\
\text { rates }\end{array}$ & $2.8 \%$ to & $23.1 \%$ to & $24.3 \%$ to \\
\hline
\end{tabular}

Table 4 reveals that a uniform inheritance tax would be accompanied by substantial tax rate cuts in tax class I, whereas considerable high top tax rates would be remaining in tax class II and III. The tax rate cuts indicate an enormous shift of the tax load in particular from businesses to the remaining asset categories in the current law.

\subsection{Contribution of businesses to tax revenue}

This chapter provides a survey of the relevance of transferred businesses for former and current inheritance tax revenue as well as for tax revenue in case of the alternative inheritance tax without tax privileges as presented above. Table 5 highlights the contribution of businesses to former, current and alternative inheritance tax revenue. Due to lack of information on the use of the tax exemptions for businesses under current tax law assumptions have to be made. We have assumed that $30 \%$ of all businesses will claim against the entire tax exemption according to Sec. 13a Para. 8 ErbStG. Furthermore, tax revenues in later periods resulting from the jobclause and the sales-clause were not taken into account.

The figures in Table 5 and in subsequent tables are calculated by ErbSiHM 1.1 based solely on the ITS 2007 population. As the SOEP data lack information on asset categories, a detailed analysis in respect of asset categories based on the SOEP-based supplementary population cannot be conducted.

Table 5 provides an impression of the magnitude of the tax privilege for businesses in former and in current German inheritance tax law. Although businesses account for almost one third of all assets (in market values) their share of tax revenue is less than $6 \%$. By contrast, businesses contributed after all more than $20 \%$ to former inheritance tax revenue. In alternative inheritance tax law businesses have a share in tax revenue of nearly $35 \%$, which exceeds the share in transferred net property. This in turn indicates that transfers of businesses take on average part in higher property brackets than the remaining asset categories.

For a first sketchy assessment of the possible harm, which the inheritance tax might cause to businesses, Table 6 depicts several figures for the subpopulation "business transfers", which only contains property transfers that in turn include businesses, differentiated according to heritages and donations. 
Table 5: Contribution of businesses to transferred net property and tax revenue

\begin{tabular}{|c|c|c|c|c|c|}
\hline & \multicolumn{5}{|l|}{ Contribution to } \\
\hline & Former tax values & Market values & Former law & Current law & Alternative law \\
\hline Business assets & $22.16 \%$ & $31.87 \%$ & $21.45 \%$ & $5 \cdot 35 \%$ & $34.89 \%$ \\
\hline Real estate & $31.25 \%$ & $33.72 \%$ & $24.61 \%$ & $35.48 \%$ & $25.98 \%$ \\
\hline Residual property & $46.59 \%$ & $34.41 \%$ & $53.94 \%$ & $59.17 \%$ & $39.13 \%$ \\
\hline Total & $100.00 \%$ & $100.00 \%$ & $100.00 \%$ & $100.00 \%$ & $100.00 \%$ \\
\hline
\end{tabular}

Table 6 delivers some interesting insights into transfers of businesses. For example, Table 6 reveals that about $40 \%$ of all businesses and with them more than two-thirds of all business assets are transferred via donation. This shows that the predominate volume of business assets is passed prearranged via donations. But, total assets are not as unequally distributed in favor of donations as business assets. This implies that transfers of a business by heritage are on average to a larger extent accompanied by other assets. Although aggregate total assets are lower in case of bequeathed businesses than in case of bestowed businesses, the contribution to tax revenue is higher in any tax law. This results from more frequent property transfers in tax class II and III which are more frequent in case of inheritance.

Additionally, the results of Table 6 allow for a first cautious appraisal of possible negative effects of the former German inheritance tax on transferred businesses. We regard business transfers via donation as not endangered by the inheritance tax as these donations, in all likelihood, only take place if the transferred business is not assessed to be endangered by the former German inheritance tax law or if a subsequent sale of the business is intended. An intermediary transfer of a business via donation will be beneficial if the income tax burden on the capital gain of the donator exceeds the income and inheritance tax burden of the donee. Such a tax arbitrage strategy can be beneficial due to the German progressive income tax.

Consequently, in respect of the former German inheritance tax we turn our attention in particular to transfers of businesses via heritage as they occur unplanned, and hence, appear especially vulnerable to liquidity problems. Nevertheless, we also account for donations to get a complete picture. With regard to an inheritance tax with no tax privileges for businesses as a possible alternative to current German inheritance tax the impact of taxation on both forms of business transfers attracts our interest likewise.

\subsection{Inheritance tax burden of businesses}

After having demonstrated that businesses are subsidized to a large extent, the question arises as to whether this appears to be necessary for their survival or if, as a result of successful lobbying, this solely serves particular interests. Consequently, the results presented in this section are based entirely on the subpopulation "business transfers".

To get a first impression of the (possible) impact of the inheritance tax on liquidity of businesses, we have computed the ratio of inheritance tax liability to total net property (tax amount quota). By calculating the average tax amount quota for all heritages and donations, which include business transfers, we have differentiated between an equally weighted and a value weighted quota. The equally weighted quota represents the average of the individual tax amount quota of every single recipient. What we call "value weighted tax amount quota" equals what is usually called average aggregate tax burden and is calculated by dividing aggregate inheritance tax revenue by aggregate transferred property. Table 7 depicts the tax amount quota.

Table 7 comprises several interesting results. We start with the higher equally weighted and valueweighted tax amount quotas of properties which are transferred rather via heritage than via donation. The differences in tax amount quota do not indicate that properties in case of succession are on average more valuable than in case of donation, as the opposite is true. The higher tax amount quotas emerge from significantly more businesses being transferred in tax class II and III in case of heritage than in case of donation. The sustainable disparity of equally weighted and value weighted tax amount quotas in case of donations is evidence of a rather 
Table 6: Business transfers according to heritage and donation

\begin{tabular}{|c|c|c|c|c|c|c|}
\hline & \multirow{2}{*}{$\begin{array}{l}\text { Contribution to } \\
\text { Number of busi- } \\
\text { ness transfers }\end{array}$} & \multirow{2}{*}{$\begin{array}{l}\text { Aggregate busi- } \\
\text { ness assets }\end{array}$} & \multirow{2}{*}{$\begin{array}{l}\text { Aggregate } \\
\text { total assets }\end{array}$} & \multicolumn{2}{|c|}{ Tax Revenue } & \multirow[b]{2}{*}{$\begin{array}{l}\text { Alternative } \\
\text { law }\end{array}$} \\
\hline & & & & $\begin{array}{l}\text { Former } \\
\text { law }\end{array}$ & $\begin{array}{l}\text { Current } \\
\text { law }\end{array}$ & \\
\hline $\begin{array}{l}\text { Transfer by } \\
\text { heritage }\end{array}$ & $60.29 \%$ & $31.14 \%$ & $47 \cdot 35 \%$ & $56.06 \%$ & $74.65 \%$ & $49.95 \%$ \\
\hline $\begin{array}{l}\text { Transfer by } \\
\text { donation }\end{array}$ & $39.71 \%$ & $68.86 \%$ & $52.65 \%$ & $43.94 \%$ & $25.35 \%$ & $50.05 \%$ \\
\hline Total & $100.00 \%$ & $100.00 \%$ & $100.00 \%$ & $100.00 \%$ & $100.00 \%$ & $100.00 \%$ \\
\hline
\end{tabular}

unequal distribution of bestowed property. In contrast, the distribution of bequeathed property which includes businesses is less unequal.

Table 7: Tax amount quota of all businesses

\begin{tabular}{|c|c|c|c|c|}
\hline & \multicolumn{2}{|c|}{ Tax amount quota } & \multicolumn{2}{|c|}{ Alternative tax law } \\
\hline & $\begin{array}{l}\text { Equally } \\
\text { weighted }\end{array}$ & $\begin{array}{l}\text { Value } \\
\text { weighted }\end{array}$ & $\begin{array}{l}\text { Equally } \\
\text { weighted }\end{array}$ & $\begin{array}{l}\text { Value } \\
\text { weighted }\end{array}$ \\
\hline $\begin{array}{l}\text { Transfer } \\
\text { by herit- } \\
\text { age }\end{array}$ & $6.67 \%$ & $8.84 \%$ & $8.06 \%$ & $8.83 \%$ \\
\hline $\begin{array}{l}\text { Transfer } \\
\text { by dona- } \\
\text { tion }\end{array}$ & $1.82 \%$ & $6.23 \%$ & $4.18 \%$ & $8.04 \%$ \\
\hline Total & $4.74 \%$ & $7.47 \%$ & $6.52 \%$ & $8.46 \%$ \\
\hline
\end{tabular}

Furthermore, Table 7 shows generally higher tax amount quotas in alternative tax law, although even higher quotas could have been expected as the contribution of businesses to tax revenue is significantly higher compared to former tax law as seen in Table 5 (34.89\% versus $21.45 \%)$. But, as we will later see in detail, transfers of businesses are very often accompanied by other assets which in turn face in alternative tax law lower tax burdens than in former tax law. The tax burden on residual property is reduced by $19 \%$ (tax class III) to $59 \%$ (tax class I) and also real estate is considerably less burdened in tax class I. As most property transfers which include businesses take place in tax class I $(57.19 \%$ of all cases and $88.07 \%$ of the volume) these tax reductions balance the tax increase for businesses to some extent or even entirely in case of the value-weighted quota of bequeathed businesses.

Table 7 allows for a first precautious conclusion even at this early stage of our empirical analysis. As the tax amount quotas are in either case far below $10 \%$, neither the former German inheritance tax nor an alternative inheritance tax, without tax privileges for businesses, are likely to endanger businesses to a large extent. But since the marginal tax rate for businesses is 30\% in former tax law and even $40.5 \%$ in alternative tax law, tax-induced damage still remains possible.

For the identification of negative effects of the inheritance tax on the liquidity positions of businesses it is inadequate to consider only tax amount quotas, as it remains unclear if the entire tax liability burdens businesses effectively. Hence, we calculate to what extent the inheritance tax liability can be covered by other assets which are transferred in addition to businesses. This means that merely the fraction of tax liability, which exceeds transferred real estate and residual property, is taken into account. Because we are interested in the tax load that has to be covered by business assets, we have divided the tax load by the market value of business assets in order to gain what we call tax load quota. In other words, the tax load quota incorporates only the part of tax liability that burdens transferred businesses effectively.

Table 8 resembles Table 7 and depicts the tax load quota.

Table 8 shows substantially lower tax load quotas compared to tax amount quotas by exemption of the value-weighted quota of bestowed businesses. This indicates that transferees of a business receive very often other assets in addition to the business which enable them to balance large parts or even the entire inheritance tax liability. In contrast to Table 7 valueweighted values exceed equally weighted values significantly in either case. 
Table 8: Tax load quota of all businesses

\begin{tabular}{|c|c|c|c|c|}
\hline & \multicolumn{4}{|c|}{ Tax load quota } \\
\hline & $\begin{array}{l}\text { Equally } \\
\text { weighted }\end{array}$ & $\begin{array}{l}\text { Value } \\
\text { weighted }\end{array}$ & $\begin{array}{l}\text { Equally } \\
\text { weighted }\end{array}$ & $\begin{array}{l}\text { Value } \\
\text { weighted }\end{array}$ \\
\hline $\begin{array}{l}\text { Transfer } \\
\text { by herit- } \\
\text { age }\end{array}$ & $0.07 \%$ & $2.21 \%$ & $0.40 \%$ & $4.16 \%$ \\
\hline $\begin{array}{l}\text { Transfer } \\
\text { by do- } \\
\text { nation }\end{array}$ & $1.12 \%$ & $5.93 \%$ & $2.99 \%$ & $7.78 \%$ \\
\hline Total & $0.49 \%$ & $4.77 \%$ & $1.43 \%$ & $6.66 \%$ \\
\hline
\end{tabular}

This indicates a highly unequal distribution of taxburdened businesses. It has to be mentioned that the tax load quotas faced by firms in reality might differ from the figures depicted in Table 8 and the subsequent text. The figures presented in this contribution do not take the time lag into account between tax base assessment and tax payment. Hence, the realized market value of non-business assets respectively the market value of businesses might differ from the market value on tax base assessment date.

Although the surprisingly low tax amount and tax load quotas displayed in Table 7 and 8 suggest no general threat of businesses, it cannot be ruled out that the inheritance tax endangers part of the businesses. There are hints that the inheritance tax could endanger valuable businesses in particular and with them many jobs. In order to tackle this issue Table 9, which is classified according to the value of the transferred net property, differentiates between businesses which do not face any tax load and those which do.

Table 9 reveals some amazing results especially in respect of bequeathed businesses. It is demonstrated that less than $2 \%$ (323 businesses) of all $(16,845)$ bequeathed businesses are effectively burdened with former German inheritance tax law.

This means that more than $98 \%$ of bequeathed businesses face no tax load at all. Even in the class of net properties over 10 million euros more than $60 \%$ of businesses are not burdened with former German inheritance tax. But although only about $2 \%$ of bequeathed businesses are burdened by former inheritance tax more than one third (36\%) of aggregate business assets are concerned. Donated businesses face in less than $30 \%$ (3,235 businesses) of all businesses $(11,097)$ a tax load in former German inheritance tax, but high-value businesses (value more than 1,000,000 euros) are burdened with tax in most cases. Hence, $76 \%$ of aggregate business assets belong to tax-burdened businesses. As the figures in Table 9 demonstrate in alternative inheritance tax law businesses face more often tax loads than in former tax law. This holds for both forms of transferring a business, heritage and donation.

Table 10 depicts the share of business assets in total assets and delivers an explanation as to why many businesses do not face a tax load although they are subject to tax. It also illustrates the reason for bestowed businesses facing a higher tax load than bequeathed businesses. Like Table 9, Table 10 is classified according to the value of the transferred net property.

Table 9: Number of tax-loaded and non-tax-loaded businesses in former and alternative German inheritance tax

\begin{tabular}{|c|c|c|c|c|c|c|c|}
\hline \multicolumn{2}{|c|}{ Value of net property in $€$} & \multicolumn{2}{|c|}{ Transfer by heritage } & \multicolumn{3}{|c|}{ Transfer by donation } & \multirow[b]{3}{*}{$\begin{array}{l}\text { Alternative } \\
\text { tax law }\end{array}$} \\
\hline From & To & All & Tax loaded & & All & Tax loaded & \\
\hline & & & $\begin{array}{l}\text { Former } \\
\text { tax law }\end{array}$ & $\begin{array}{l}\text { Alternative } \\
\text { tax law }\end{array}$ & & $\begin{array}{l}\text { Former Tax } \\
\text { law }\end{array}$ & \\
\hline o & 20,000 & 2,051 & 5 & 11 & 705 & 132 & 3 \\
\hline 20,001 & 100,000 & 4,984 & 28 & 118 & 1,699 & 281 & 398 \\
\hline 100,001 & 500,000 & 5,817 & 49 & 210 & 4,191 & 554 & 947 \\
\hline 500,001 & $1,000,000$ & 2,058 & 49 & 115 & 2,513 & 726 & 1,786 \\
\hline $1,000,001$ & $10,000,000$ & 1,838 & 154 & 217 & 1,876 & 1,432 & 1,547 \\
\hline Beyond & & 97 & 38 & 45 & 113 & 110 & 102 \\
\hline Total & & 16,845 & 323 & 716 & 11,097 & 3,235 & 4,783 \\
\hline
\end{tabular}


Table 10: Share of business assets in total assets according to net property classes

\begin{tabular}{rrrr}
\multicolumn{2}{l}{$\begin{array}{l}\text { Value of net property in } \\
\text { euros } \\
\text { From }\end{array}$} & \multicolumn{1}{c}{$\begin{array}{l}\text { To } \\
\text { Transfer } \\
\text { by herit- } \\
\text { age }\end{array}$} & $\begin{array}{l}\text { Transfer } \\
\text { by dona- } \\
\text { tion }\end{array}$ \\
\hline 0 & 20,000 & $10.97 \%$ & $79.71 \%$ \\
\hline 20,001 & 100,000 & $16.20 \%$ & $73.26 \%$ \\
\hline 100,001 & 500,000 & $21.02 \%$ & $80.14 \%$ \\
\hline 500,001 & $1,000,000$ & $31.18 \%$ & $91.11 \%$ \\
\hline $1,000,001$ & $10,000,000$ & $46.80 \%$ & $94.68 \%$ \\
\hline Beyond & & $76.52 \%$ & $99.34 \%$ \\
\hline Total & & $47.18 \%$ & $93.85 \%$ \\
\hline
\end{tabular}

Table 10 reveals a rather different structure of the composition of total assets between transfers via heritage and donation. Businesses are throughout the predominant source of assets in case of donation. We suppose that, in most instances, donators keep most of their other assets, which is not possible in case of inheritance. Another possible explanation, but in our opinion less likely, could be delivered by a special interest of donators in the survival of their business. To achieve this goal, they might invest all their fortune in the business and transfer this via donation to secure its survival. If transferred net property exceeds 500,000 euros businesses even amount to more than $90 \%$ of total assets. Therefore, the inheritance tax liability has to be balanced widely by business assets or other sources of the transferee. Transfers of businesses via heritage are accompanied to a far larger extent by assets other than donations. Even properties worth more than 10 million euros include (on average) almost $25 \%$ of other assets, which can be used to meet or mitigate inheritance tax liability. These findings contrast with the frequently given statement that the bulk of an entrepreneur's estate consists of business assets and relatively little liquid assets (see, e.g., Brunetti 2006: 1976). Table 10 shows a good explanation for the, on average, rather low tax load quota, as businesses are, on average, by far not the only transferred asset category.

Up to now it can be asserted that neither the former German inheritance tax nor the alternative inheritance tax is a threat for the vast majority of businesses. But as the businesses which are hit by the inheritance tax possess a large share in total business assets, it cannot be ruled out that the inheritance tax causes severe damage to affected busi- nesses. Hence, in the subsequent analysis we quantify the magnitude of tax loads. Consequently, the subsequent remarks concentrate on the subpopulation of tax-loaded businesses.

Table 11 displays tax load quotas of tax-burdened businesses.

\section{Table 11: Tax load quota of tax-burdened businesses}

\begin{tabular}{lllll}
\multicolumn{1}{c}{ Tax load quota } & \multicolumn{2}{l}{$\begin{array}{l}\text { Former } \\
\text { tax law }\end{array}$} & & $\begin{array}{l}\text { Alternative } \\
\text { tax law }\end{array}$ \\
\hline & $\begin{array}{l}\text { Equally } \\
\text { weighted }\end{array}$ & $\begin{array}{l}\text { Value } \\
\text { weighted }\end{array}$ & $\begin{array}{l}\text { Equally } \\
\text { weighted }\end{array}$ & $\begin{array}{l}\text { Value } \\
\text { weighted }\end{array}$ \\
\hline $\begin{array}{l}\text { Trans- } \\
\text { fer by } \\
\text { herit- } \\
\text { age }\end{array}$ & $3.80 \%$ & $6.18 \%$ & $9.50 \%$ & $9.73 \%$ \\
\hline $\begin{array}{l}\text { Trans- } \\
\text { fer by } \\
\text { dona- } \\
\text { tion }\end{array}$ & $3.83 \%$ & $7.82 \%$ & $6.93 \%$ & $9.30 \%$ \\
\hline Total & $3.83 \%$ & $7.53 \%$ & $7.27 \%$ & $9.38 \%$ \\
\hline
\end{tabular}

Compared to the figures for all businesses presented in Table 8, both tax load quotas, equally weighted and value weighted, are considerably higher. But, on average the tax load of businesses in former tax law is in either case below $8 \%$ and in alternative tax law below $10 \%$. As we consider a tax load quota of up to $10 \%$ not as a serious threat for businesses, it can be stated that even tax-burdened businesses are in general not endangered by German inheritance tax. We have chosen the threshold of $10 \%$ because we suppose that, in many cases, either the firm or the successor own sufficient liquid assets to balance the tax payment. Otherwise, it should not cause severe problems to receive a suitable loan.

But for an appraisal of the potential harm of the inheritance tax the scale of tax loads for individual businesses is relevant. Since the impact of the inheritance tax on liquidity is decisive for the survival of every single firm, the subsequent tables only contain equally weighted tax quotas.

Figure 1a and $1 \mathrm{~b}$ display the tax load quota in former German tax law according to the market value of businesses in a Box-Whisker Plot extending to the $5^{\text {th }}$ and $95^{\text {th }}$ percentiles. In the following tables we employ market value of business assets instead of net property for classification purposes as we are focusing the tax load of businesses. 
The classification in figures $1 \mathrm{a}$ to $2 \mathrm{~b}$ refers to figures between 1 and 5, where 1 represents the business assets value class up to 100,000 euros, 2 the business assets value class up 500,000 euros, 3 the business assets value class up 1,000,000 euros, 4 the business assets value class up 10,000,000 euros and 5 the business assets value class beyond $10,000,000$ euros.

\section{Figure 1a: Tax load quota of bequeathed businesses in former German tax law} tax load quota

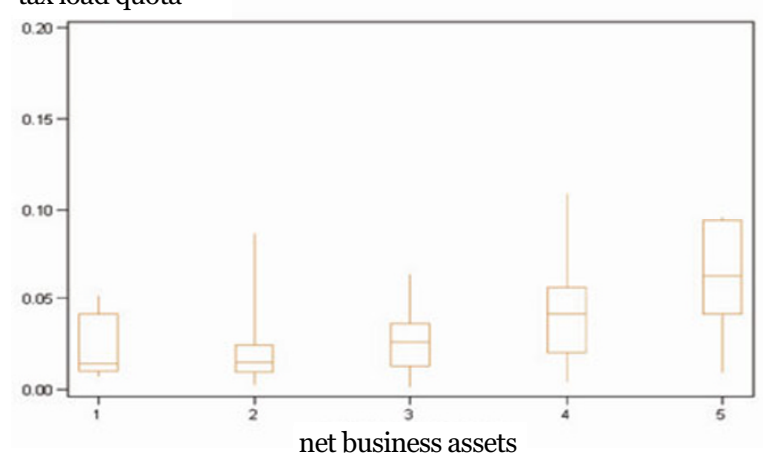

Figure 1a reveals a tax load quota of below $5 \%$ for the vast majority of businesses (71\%) which possess $40 \%$ of all business assets. Even $75 \%$ of all businesses, which are passed in a business assets range between one to ten million euros (class 4), face a tax load of less than $6 \%$. For $50 \%$ of businesses with a business assets value above 10 million euros tax load quota is below $7 \%$. For the remaining businesses within this business assets class the tax load quota in $95 \%$ falls below $10 \%$. Tax load quotas above $15 \%$ hit only 3 businesses.

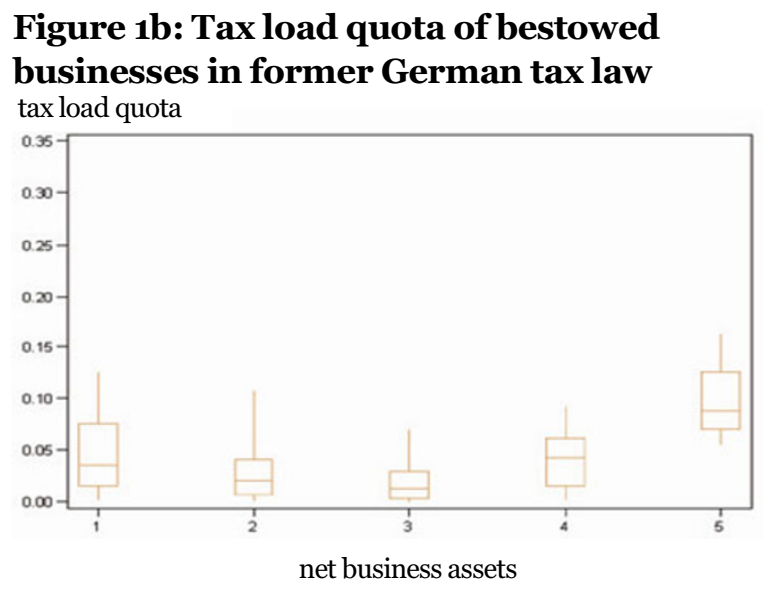

The figures for bestowed businesses do not highly differ from the results presented above. The most significant difference is more businesses with a tax load quota over $10 \%$ although only 31 (0.96\%) busi- nesses which possess $6.56 \%$ of all business assets face a tax load quota over $15 \%$. Furthermore, lowvalue businesses (business assets value below 100,000 euros (class 1)) face higher tax loads. This results from more businesses being passed to transferees in tax class II and III than in case of heritage. Summing up, the results for the former German inheritance tax lead to the conclusion that the former German inheritance tax does not endanger bequeathed businesses. Only few businesses face tax load quotas above $10 \%$ and therefore may have problems of financing (parts of) the inheritance tax. For bestowed businesses the results reveal that plans of donating a business do not fail due to former German inheritance tax.

The conclusions for the alternative inheritance tax are by far less clear-cut as Figure $2 \mathrm{a}$ and $2 \mathrm{~b}$ depict.

Figure 2a: Tax load quota of bequeathed businesses in alternative German tax law tax load quota

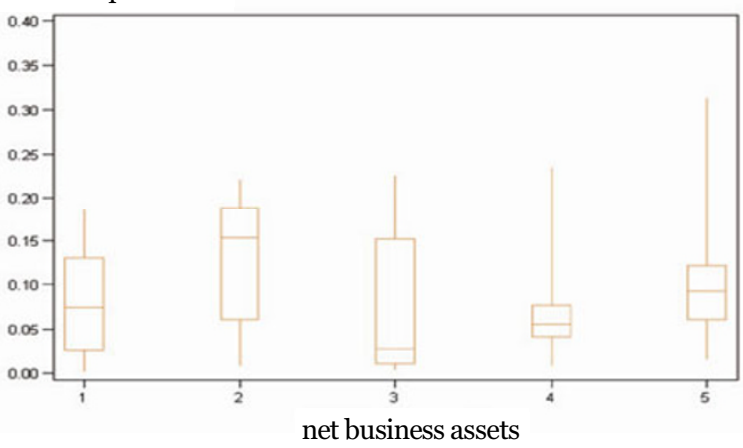

Figure 2a reveals a distinctly higher tax load of bequeathed businesses in many cases than in former tax law. In particular, businesses with a value up to 1,000,000 euros (classes 1 to 3 ) face substantially higher tax load quotas. Additionally, tax load quotas over $10 \%$ happen in $39.4 \%$ of all cases and affect $46.3 \%$ of total business assets. Even tax load quotas over $15 \%$ are not uncommon as $27.79 \%$ of all businesses, which possess $11.06 \%$ of total business assets, are affected. Even peak values over 30\% affect 5 businesses. These rather high tax load quotas mainly result from the high tax rates in tax classes II and III.

The results for bestowed businesses are similar to bequeathed businesses in net business assets class 2 and 3 as businesses worth up to 500,000 euros are often passed to transferees in tax class II or III. The remaining businesses face, if that, only moderately higher tax load quotas in alternative tax law. This results in $21.6 \%$ of all businesses which possess 
$37.2 \%$ of total business assets facing a tax load quota of above $10 \%$. Furthermore, $17.2 \%$ of all businesses with $8.4 \%$ of total assets are burdened above $15 \%$. A tax load quota over $30 \%$ affects 9 businesses which incorporate $4.2 \%$ of total business assets. To what extent donations of businesses would be hindered by the alternative inheritance tax depends on the existence of other assets. If donators keep other assets and only or primarily transfer their business, then the alternative inheritance tax should not cause severe problems in too many cases. But if the business is the primary source of fortune of the donator, the alternative inheritance tax might retard business transfers to some extent.

\section{Figure 2b: Tax load quota of bestowed businesses in alternative German tax law tax load quota}

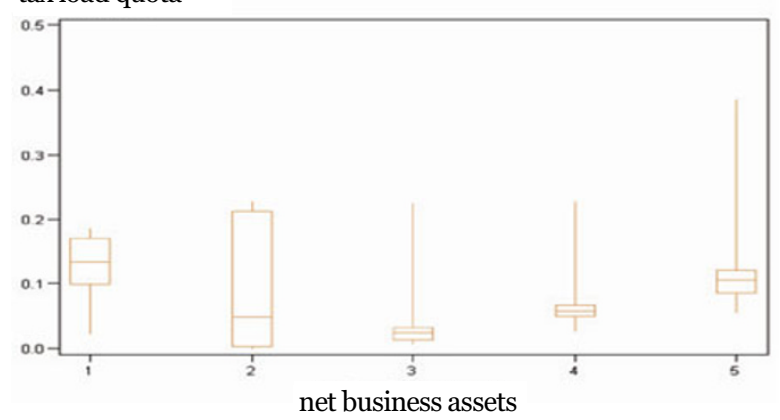

Unfortunately, the conclusions for the alternative inheritance tax are not as straightforward as for the former German inheritance tax. In contrast to the latter, tax load quotas over 10\% are not an exception in the alternative inheritance tax. Even higher tax load quotas are common. Relating tax load quotas over $10 \%$ to all transferred businesses modify the findings slightly as only $4.7 \%$ of all businesses face tax load quotas of this amount. But, as these businesses incorporate $27.6 \%$ of total business assets it cannot be ruled out entirely that the alternative inheritance tax might cause some serious damage. Because the very high tax rates in tax classes II and III are primarily accountable for this outcome, alternative inheritance tax reform scenarios with lower tax rates could be taken into account.

The potential harm, especially of the alternative inheritance tax, is reduced if an income tax shield for paid inheritance tax is provided. Such a tax shield has been phased in for bequeathed businesses in German Income Tax Law by 2009 (Sec. 35b EStG) and reduces the negative liquidity effect of the inheritance tax.

\section{Conclusion}

The presented empirical results suggest that the enormous tax privileges for businesses established by the German Inheritance Tax Reform Act 2009 are the outcome of successful lobbying, but cannot be justified as a protection of businesses. The former German inheritance tax which also provided tax privileges for businesses, but to a far lower extent, burdens bequeathed businesses, if at all, only moderately. Since bequeathed businesses are accompanied to a large extent by other assets, most or even all of the inheritance tax liability does not burden business assets. Businesses which were transferred via donation in former inheritance tax law do not seem to be damaged by the tax. Otherwise entrepreneurs would have postponed the transfer of their businesses. As the bestowed businesses face moderate tax burdens the former German inheritance tax appear not as an obstacle for the donation of businesses.

The conclusion for an alternative inheritance tax with a broad tax base and lower tax rates, as considered in this contribution as an alternative to the current inheritance tax, is not clear-cut. This alternative inheritance tax provides relatively high tax rates in tax class II and III as a result of assumed tax neutrality per tax class. Although most of all transferred businesses are not burdened by this alternative inheritance tax, a small fraction faces relatively high tax burdens. Since these businesses incorporate about one quarter of total business assets, inheritance-tax-induced damage cannot be ruled out entirely.

\section{References}

Astrachan, Joseph H. and Roger Tutterow (1996): The Effect of Estate Taxes on Family Business: Survey Results, Family Business Review, 9 (3): 303-314.

Bach, Stefan, Wiebke Broekelschen, and Ralf Maiterth (2006): Gleichmäßige erbschaftsteuerliche Behandlung von Grund- und Betriebsvermögen: Anmerkungen zum anstehenden Bundesverfassungsgerichtsurteil, Deutsches Steuerrecht, 44 (44): 1961-1968.

Bennedsen, Morten, Kasper Meisner Nielsen, Francisco PérezGonzález, and Daniel Wolfenzon (2007): Inside the Family Firm: the Role of Families in Succession Decisions and Performance, The Quarterly Journal of Economics, 122 (2): 647-691.

Bloom, Nick and John Van Reenen (2006): Management Practices, Work-Life Balance, and Productivity: A Review of Some Recent Evidence, Oxford Review of Economic Policy, 22 (4): 457482. 
Broekelschen, Wiebke and Ralf Maiterth (2008): Bewertung bebauter Grundstücke für steuerliche Zwecke nach dem BVerfGUrteil, Die Betriebswirtschaft, 68 (5): 525-544.

Brunetti, Michael J. (2006): The Estate Tax and the Demise of the Family Business, Journal of Public Economics, 90 (10/11): 19751993.

Burman, Leonard E., William G. Gale, and Jeffrey Rohaly (2005): Options for Reforming the Estate Tax, Tax Notes, 107 (3): 379385 .

Grossmann, Volker and Holger Strulik (2010): Should Continued Family Firms Face Lower Taxes Than Other Estates?, Journal of Public Economics, 94 (1-2): 87-101.

Harriss, C. Lowell (1949): Liquidity of Estates and Death Tax Liability, Political Science Quarterly, 64 (4): 533-559.

Hey, Johanna (2007): BVerfG zur Erbschaftsteuer: Bewertungsgleichmaß und Gemeinwohlzwecke, JuristenZeitung, 62 (11): 564-574.

Holtz-Eakin, Douglas (1999): The Death Tax: Impact on Investment, Employment, and Entrepreneurs, http://www.accf.org/ publications/91/the-death-tax (Access date: 2011-03-11).

Holtz-Eakin, Douglas, John W. R. Phillips, and Harvey S. Rosen (2001): Estate Taxes, Life Insurance, and Small Business, The Review of Economics and Statistics, 83 (1): 52-63.

Houben, Henriette and Ralf Maiterth (2010): ErbSiHM o.1, Working Paper, arqus, http://www.arqus.info/paper/arqus_102. pdf (Access date: 2011-03-11).

Jansen, Harald (2006): Erbschaftsteuerliche Wirkungen bei Vermögensübertragungen: Entscheidungswirkungen und Gleichmäßigkeit der Besteuerung, Schmidt: Berlin.

Maiterth, Ralf, Rainer Niemann, Kay Blaufus, Dirk Kiesewetter, Deborah Knirsch, Rolf König, Jochen Hundsdoerfer, Heiko Müller, Caren Sureth, and Corinna Treisch (2006): arqusStellungnahme zur faktischen Abschaffung der Erbschaftsteuer für Unternehmer, Der Betrieb, 59 (50): 2700-2702.

Maiterth, Ralf and Caren Sureth (2007): Aufkommenswirkungen des Erbschaftsteuerreformvorschlags der CDU/CSU-Mittelstandsvereinigung, http://www.bertelsmann-stiftung.de/bst/de/ media/xcms_bst_dms_21797_21798_2.pdf (Access date: 201103-11).

Morck, Randall, Andrei Shleifer, and Robert W. Vishny (1989): Alternative Mechanisms for Corporate Control, The American Economic Review, 79 (4): 842-852.

Pérez-González, Francisco (2006): Inherited Control and Firm Performance, The American Economic Review, 96 (5): 15591588 .
Sachverständigenrat zur Begutachtung der gesamtwirtschaftlichen Entwicklung (2005): Jahresgutachten 2005/o6: Die Chance nutzen - Reformen mutig voranbringen, http://www.sachverstaendigenrat-wirtschaft.de / fileadmin / dateiablage / download / gutachten/gao5_ges.pdf (Access date: 2011-03-11).

Sachverständigenrat zur Begutachtung der gesamtwirtschaftlichen Entwicklung (2008): Jahresgutachten 2008/o9: Die Finanzkrise meistern - Wachstumskräfte stärken, http://www.sachverstaendigenrat-wirtschaft.de / fileadmin / dateiablage / download/gutachten/gao8_ges.pdf (Access date: 2011-03-11).

Schneider, Friedrich and Dominik Enste (200o): Schattenwirtschaft und Schwarzarbeit: Umfang, Ursachen, Wirkungen und wirtschaftspolitische Empfehlungen, Oldenbourg: München/Wien.

Sureth, Caren, Jens Müller, Henriette Houben, and Ralf Maiterth (2008): Auswirkungen einer Reform des Erbschaft- und Schenkungsteuergesetzes auf das Steueraufkommen unter besonderer Berücksichtigung einer verkehrswertorientierten Bewertung von Unternehmens- und Grundvermögen, in: Oestreicher, Andreas (ed.), Unternehmensbesteuerung 2008: Neue Wege gehen, nwb: Herne, 183-200.

Travis Research Associates Inc. (1995): Federal Estate Tax Impact Survey, Center for the Study of Taxation, http://www. policyandtaxationgroup.com / pdf / FederalEstateTaxSurvey.pdf (Access date: 2011-03-11).

Villalonga, Belen and Raphael Amit (2006): How do family ownership, control and management affect firm value?, Journal of Financial Economics, 80 (2): 385-417.

\section{Biographies}

Henriette Houben is assistant professor at the Institute of Business Taxation at the Leibniz University of Hannover. She received her Diploma in Business Administration at the Humboldt University of Berlin in 2004 and her Doctoral Degree at the Leibniz University of Hannover in 2009. Her main fields of research are empirical tax analyzes, including the use of economictheoretic methods.

Ralf Maiterth has held the Chair of Business Taxation at the Leibniz University of Hannover from 2005 to 2009 and the Chair of Business taxation at the Humboldt University of Berlin since 2009. He studied Economics at Augsburg University and Würzburg University and received his Diploma in 1993. In 1999 he received his Doctoral Degree at the Humboldt University of Berlin. His main fields of research are empirical tax analyzes based on economic-theoretic methods, particularly with regard to taxation effects in consequence of tax reforms. 